\title{
Keterkaitan Ekonomi Perdesaan Dan Perkotaan Di Daerah Tertinggal (Kasus Kabupaten Aceh Singkil)
}

\author{
Sendi Permana, R. Rijanta dan Dyah Rahmawati Hizbaron
}

Masuk: 12062019 / Diterima: 24062019 / Dipublikasi: 30062019

C 2019 Fakultas Hukum dan IImu Sosial UNDIKSHA dan IGI

\begin{abstract}
Aceh Singkil District is one of several District with status as underdeveloped regions. There are indications that the linkages between urban centers and rural area cannot fully accommodate the development of the plantation sector which is the basis of the activities of the region. This resulted in the regional development process isn't optimal and haven't contributed significantly to the community welfare. This research aims to analyze the economic linkages between rural and urban in underdeveloped region. The method of this study is descriptive survey by collecting data through interviews. The results showed that most farmer groups had not accessed capital facilities in urban areas, while the needs of production facilities could mostly be provided by sellers of production facilities in rural areas. While the flow of production raw materials is interwoven in rural areas. Most product distribution is carried out by village agents to the previous collection unit to the factory. The long chain of sales of oil palm fruit bunches contributes to the low income received by farmers. The income received by farmers is far below the from minimum wage that applicable in this province. In addition, industrial activities developed through private coconut oil processing plants are limited to the production area of CPO (Crude Palm Oil). All products are sent through the Belawan port located in Medan City, so that the added value is approved to enter the Medan City.
\end{abstract}

Key words Economic Linkages; Rural Urban; Underdeveloped Regions

\begin{abstract}
Abstrak Pembangunan wilayah di Kabupaten Aceh Singkil masih dihadapkan pada kesenjangan pembangunan antara perdesaan dan perkotaan. Terdapat indikasi bahwa keterkaitan antara perdesaan dan perkotaan belum sepenuhnya dapat mengakomodir pengembangan sektor perkebunan yang menjadi basis kegiatan wilayahnya. Hal ini mengakibatkan proses pembangunan daerah tidak berjalan dengan optimal dan belum memberikan kontribusi yang signifikan terhadap kesejahteraan masyarakat. Penelitian ini bertujuan untuk menganalisis keterkaitan ekonomi antara perdesaan dan perkotaan di daerah tertinggal. Metode yang digunakan dalam penelitian ini adalah survei deskriptif dengan pengumpulan data melalui wawancara. Hasil penelitian menunjukan bahwa sebagian besar kelompok tani belum mengakses fasilitas pelayanan permodalan yang terdapat di perkotaan, sedangkan kebutuhan sarana produksi sebagian besar dapat dipenuhi oleh toko penjual sarana produksi yang berada di perdesaan. Adapun aliran bahan baku hasil produksi perkebunan terjalin di wilayah perdesaan dan pendistribusian hasil produksi perkebunan sebagian besar dilakukan oleh agen desa ke satuan pengumpul lalu ke pabrik. Rantai penjualan tandan buah sawit yang panjang turut menyebabkan minimnya pendapatan yang diterima petani. Adapun pendapatan yang diterima petani jauh dibawah standar UMR (Upah Minimum Regional) yang berlaku. Selain itu, kegiatan industri yang dikembangkan melalui pabrik pengolahan minyak kelapa swasta hanya sebatas area produksi CPO (Crude Palm Oil). Seluruh hasil produksi CPO diekspor melalui pelabuhan Belawan yang berlokasi di Kota Medan, sehingga perolehan nilai tambah (add value) masuk ke wilayah Kota Medan.
\end{abstract}

Kata kunci : Keterkaitan Ekonomi; Desa-Kota; Daerah Tertinggal

\section{Pendahuluan}

Indonesia merupakan salah satu negara yang sedang berkembang dan memiliki masalah dalam pemerataan

Sendi Permana, R. Rijanta dan Dyah Rahmawati Hizbaron

Fakultas Geografi, Universitas Gadjah Mada Yogyakarta sendipermana123@yahoo.com pembangunan, hal ini turut berimplikasi atas terbentuknya daerah tertinggal. Berdasarkan RPJMN 2015-2019 ditetapkan 122 Kabupaten sebagai daerah tertinggal. Penetapan ini ditegaskan oleh Peraturan Presiden (Perpres) Nomor 131 tahun 2015. Adapun sebaran daerah tertinggal di Indonesia mayoritas berada di 
Kawasan Timur Indonesia, yakni 103 Kabupaten $(84,42 \%)$ dan terdapat pula 19 Kabupaten (15,58\%) berada di Kawasan Barat Indonesia.

Provinsi Aceh terletak di Pulau Sumatera dan paling barat Indonesia. Perekonomian Provinsi Aceh mengalami pertumbuhan yang relatif tinggi, hal ini ditandai dengan laju perekonomian Aceh pada tahun 2016 mengalami peningkatan dibandingkan tahun sebelumnya, yakni dari $-0,73 \%$ pada tahun 2015 , menjadi sebesar 3,31\% tahun 2016 (BPS Provinsi Aceh, 2017). Namun dibalik pertumbuhan ekonominya yang semakin meningkat, ada kesenjangan yang semakin lebar di setiap Kabupaten/Kota di dalamnya. Pada dasarnya pembangunan di Provinsi Aceh belum merata di setiap Kabupaten/Kota. Penyebab kesenjangan tersebut salah satunya adalah terbatasnya sarana dan prasarana bagi masyarakat (Bappenas, 2016).

Terdapat 23 Kabupaten/Kota dalam lingkup administrasi Provinsi Aceh. Dari sejumlah Kabupaten/Kota di Provinsi Aceh tersebut, Kabupaten Aceh Singkil adalah satu-satunya daerah yang masih berstatus tertinggal pada periode 20152019. Kabupaten Aceh Singkil merupakan salah satu Daerah Otonomi Baru (DOB) di Provinsi Aceh. Kabupaten Aceh Singkil ialah wilayah pemekaran dari Kabupaten Aceh Selatan yang ditegaskan melalui Undang-Undang Nomor 14 tahun 1999.

$$
\text { Kabupaten Aceh Singkil }
$$

sebenarnya memiliki sumberdaya alam yang sangat potensial untuk dikembangkan khususnya pada sektor pertanian. Kontribusi dari sektor pertanian menempati urutan pertama terhadap perekonomian Aceh Singkil yaitu sebesar 29,02\% (BPS Kabupaten Aceh Singkil, 2017). Hasil dari sektor pertanian di Kabupaten Aceh Singkil ini sebagian besar disuplai dari subsektor perkebunan yakni sebesar 12,51\%. (BPS Kabupaten Aceh Singkil, 2017). Adapun luas lahan dan produktivitas komoditas perkebunan yang paling tinggi adalah kelapa sawit, yakni dengan persentase luas lahan sebesar $60,74 \%$ dan persentase produktivitas sebesar $73,91 \%$ (Dinas Kehutaan dan Perkebunan Kabupaten Aceh Singkil, 2017)

Selaras dengan itu, pertanian juga merupakan lapangan usaha yang paling banyak menyerap tenaga kerja dengan mata pencaharian utama dalam skala rumah tangga didominasi oleh rumah tangga perkebunan sebesar $42,24 \%$ (BPS Kabupaten Aceh Singkil, 2017). Potensi sektor perkebunan juga didukung oleh keberadaan perusahaan kelapa sawit yang memiliki pabrik pengolahan minyak sawit atau Crude Palm Oil (CPO).

Secara teori, besarnya potensi perkebunan dan adanya kegiatan industri pengolahan kelapa sawit dapat membantu meningkatkan perekonomian masyarakat dan daerah. Namun tingginya produktivitas komoditas kelapa sawit dan keberadaan perusahaan sawit tersebut belum memberikan perubahan, khususnya terhadap kesejahteraan masyarakat. Hal ini ditandai dengan masih tingginya persentase penduduk miskin sampai tahun 2016, yaitu sebesar $21,60 \%$ (BPS Kabupaten Aceh Singkil, 2017).

Fenomena kemiskinan dan daerah tertinggal erat kaitannya dengan interaksi keruangan perdesaan dan perkotaan, khususnya dalam konteks keterkaitan ekonomi. Menurut Rondinelli (1985) keterkaitan ekonomi adalah hubungan jaringan pasar melalui aliran barang dan jasa yang terdiri dari beberapa indikator yakni: (1) pola pemasaran, (2) aliran bahan baku dan barang setengah jadi, (3) aliran modal, (4) keterkaitan produksi, (5) pola belanja dan konsumsi, (6) pola kepemilikan kegiatan ekonomi, (7) aliran pendapatan, dan (8) aliran komoditi lintas sektoral dan lintas regional. Rondinelli (1983) menegaskan bahwa pencapaian pemerataan pertumbuhan ekonomi dapat 
terjadi melalui sistem spasial yang mengintegrasikan pembangunan perkotaan dan perdesaan.

Terdapat indikasi bahwa keterkaitan ekonomi perdesaan yang berbasis perkebunan dan interaksinya terhadap fasilitas pelayanan pendukung usaha perkebunan yang terdapat di perkotaan belum terjalin secara optimal. Akibatnya, perkembangan perkotaan dan perdesaan berlangsung dengan tidak sinergis, padahal idealnya perkotaan berperan sebagai pusat pelayanan permukiman yang dapat menyediakan pelayanan sosial ekonomi bagi perdesaan atau belakangnya.

Permasalahan yang telah diuraikan tersebut perlu mendapat perhatian khusus, hal ini berkenaan dengan status Kabupaten Aceh Singkil sebagai daerah tertinggal. Oleh karena itu, diperlukan adanya tinjauan terhadap pemanfaatan ruang perdesaan dan sumberdaya wilayah yang didasarkan pada keterkaitan ekonomi yang terbentuk. Analisis keterkaitan ekonomi menekankan pada rekonstruksi proses keruangan yang diidentifikasi melalui interaksi ekonomi yang terjalin antara perdesaan dan perkotaan

Berdasarkan tinjauan permasalahan tersebut, maka rumusan masalah yang menjadi fokus penelitian ini adalah hubungan keterkaitan ekonomi perdesaan dan perkotaan di daerah tertinggal. Aliran produksi hasil perkebunan dan interaksi terhadap fasilitas pelayanan perkotaan merupakan indikator adanya proses keterkaitan ekonomi perdesaan dan perkotaan di Kabupaten Aceh Singkil.

\section{Metode}

Penelitian tentang keterkaitan ekonomi perdesaan dan perkotaan ini menggunakan metode survei dekriptif yang berbasis pada data primer. Data primer dihimpun menggunakan teknik wawancara dengan tujuan untuk memperoleh informasi mengenai keterkaitan ekonomi perdesaan dan perkotaan.

Perkotaan adalah status suatu wilayah administrasi setingkat desa/kelurahan yang memenuhi kriteria klasifikasi wilayah perkotaan, sedangkan perdesaan adalah status suatu wilayah administrasi setingkat desa/kelurahan yang belum memenuhi kriteria klasifikasi wilayah perkotaan. Kriteria wilayah perkotaan adalah persyaratan tertentu dalam hal kepadatan penduduk, persentase rumah tangga pertanian, dan keberadaan/akses pada fasilitas perkotaan, yang dimiliki suatu desa/kelurahan untuk menentukan status perkotaan suatu desa/kelurahan (BPS, 2010).

Penentuan nilai/skor untuk menetapkan sebagai wilayah perkotaan dan perdesaan atas desa/kelurahan, yaitu: (1) wilayah perkotaan, apabila dari kepadatan penduduk, persentase rumah tangga pertanian, dan keberadaan/akses pada fasilitas perkotaan yang dimiliki mempunyai total nilai/skor 10 (sepuluh) atau lebih, dan (2) wilayah perdesaan, apabila dari kepadatan penduduk, persentase rumah tangga pertanian, dan keberadaan/akses pada fasilitas perkotaan yang dimiliki mempunyai total nilai/skor di bawah 10 (sepuluh). Informasi nilai/skor tiap parameter dapat dilihat pada Tabel 1.

Lokasi penelitian berada di Kabupaten Aceh Singkil yang secara administrasi terdiri dari 116 Desa. Adapun klasifikasi Desa Perdesaan dan Desa Perkotaan di Kabupaten Aceh Singkil mengacu pada Perka BPS No 37 Tahun 2010 terdiri dari 103 Desa Perdesaan dan 13 Desa Perkotaan. Peta Perdesaan dan Perkotaan di Kabupaten Aceh Singkil dapat dilihat pada Gambar 1. 
Tabel 1. Nilai/Skor Kepadatan Penduduk, Persentase Rumah Tangga Pertanian, Dan Keberadaan/Akses Pada Fasilitas Perkotaan

\begin{tabular}{|c|c|c|c|c|c|c|}
\hline \multicolumn{4}{|c|}{ Kriteria } & \multicolumn{3}{|c|}{ Keberadaan pada fasilitas perkotaan } \\
\hline $\begin{array}{l}\text { Kepadatan } \\
\text { Penduduk }\end{array}$ & $\begin{array}{l}\text { Nilai/ } \\
\text { Skor }\end{array}$ & $\begin{array}{c}\text { Persentase } \\
\text { Rumah Tangga } \\
\text { Pertanian }\end{array}$ & $\begin{array}{l}\text { Nilai/ } \\
\text { Skor }\end{array}$ & Fasilitas Perkotaan & Kriteria & $\begin{array}{l}\text { Nilai/ } \\
\text { Skor }\end{array}$ \\
\hline 500 & 1 & $>70,0$ & 1 & $\begin{array}{l}\text { Sekolah Taman } \\
\text { Kanak-Kanak }\end{array}$ & & 1 \\
\hline $500-1249$ & 2 & $50,00-69,99$ & 2 & $\begin{array}{l}\text { Sekolah Menengah } \\
\text { Pertama }\end{array}$ & $>2,5 \mathrm{Km}^{*}$ & 0 \\
\hline $1250-2499$ & 3 & $30,00-49,99$ & 3 & $\begin{array}{l}\text { Sekolah Menengah } \\
\text { Umum }\end{array}$ & & \\
\hline $2500-3999$ & 4 & $20,00-29,99$ & 4 & Pasar & - Ada atau $\leq 2 \mathrm{Km}$ * & 1 \\
\hline $4000-5999$ & 5 & $15,00-19,99$ & 5 & Pertokoan & - $>2 \mathrm{Km}$ * & 0 \\
\hline $\begin{array}{l}6000-7499 \\
7500-8499\end{array}$ & $\begin{array}{l}6 \\
7\end{array}$ & $\begin{array}{c}10,00-14,99 \\
5.00-9.99\end{array}$ & $\begin{array}{l}6 \\
7\end{array}$ & $\begin{array}{l}\text { Bioskop } \\
\text { Rumah Sakit }\end{array}$ & $\begin{array}{l}\text { - Ada atau } \leq 5 \mathrm{Km} \text { * } \\
\text { - }>5 \mathrm{Km}^{*}\end{array}$ & $\begin{array}{l}1 \\
0\end{array}$ \\
\hline$>8500$ & 8 & 5,00 & 8 & $\begin{array}{l}\text { Hotel/Bilyar/ } \\
\text { Diskotek/Panti } \\
\text { Pijat/Salon } \\
\text { Persentase Rumah } \\
\text { Tangga yang } \\
\text { menggunakan } \\
\text { Telepon } \\
\text { Persentase Rumah } \\
\text { Tangga yang } \\
\text { menggunakan Listrik }\end{array}$ & $\begin{array}{l}\text { - } \text { Ada } \\
\text { - Tidak ada } \\
\text { - } \geq 8,00 \mathrm{Km}^{*} \\
\text { - }<8,00 \mathrm{Km}^{*} \\
\text { - } \geq 8,00 \mathrm{Km}^{*} \\
\text { - }<8,00 \mathrm{Km}^{*}\end{array}$ & $\begin{array}{l}1 \\
0 \\
1 \\
0\end{array}$ \\
\hline
\end{tabular}

Catatan: (*) Jarak tempuh diukur dari kantor Desa/Kelurahan Sumber: Perka BPS No 37 Tahun 2010

Keterkaitan ekonomi antara perdesaan dan perkotaan dalam penelitian ini ditinjau dalam beberapa indikator, yakni: aliran modal, (2) aliran belanja, (3) aliran bahan baku, (4) aliran barang setengah jadi, dan (5) aliran pendapatan (Rondinelli, 1985). Adapun responden yang ditujukan dalam penelitian ini terdiri dari ketua kelompok tani dan Kepala Tata Usaha (KTU) pabrik pengolahan minyak kelapa sawit

Pemilihan lokasi survei kelompok tani dilakukan dengan metode proportional stratified random sampling dengan didasarkan pada klasifikasi luas lahan (tinggi, sedang, dan rendah) menurut luas perkebunan rakyat tiap Kecamatan. Kecamatan yang terpilih sebagai lokasi survei yaitu: (1) Kecamatan Gunung Meriah, (2) Simpang Kanan, dan (3) Singkil. Berdasarkan lokasi survei terpilih, maka ketua kelompok tani yang ditujukan sebagai responden diambil secara acak dan proporsional. Ketua kelompok tani yang terpilih tersebar di 3 Kecamatan, yaitu: (1) Kecamatan Gunung Meriah: (a)
Kelompok tani Sekata di Desa Penjahitan, (b) Kelompok tani Doa Bersama di Desa Sidorejo, (c) Kelompok tani Jamaah Karya di Desa Tanah Bara, (2) Kecamatan Simpang kanan: (a) Kelompok tani Ingin Maju di Desa Sidodadi, (b) Kelompok tani Maju Sejahtera di Desa Sukarejo, dan Kecamatan Singkil: (a) Kelompok tani Endarno di Desa Ujung Bawang.

Adapun pemilihan lokasi survei pabrik pengolahan kelapa sawit dalam penelitian ini juga dengan metode proportional stratified random sampling dengan didasarkan pada klasifikasi luas lahan perkebunan swasta (tinggi, sedang, dan rendah) yang terkait dengan pabrik minyak kelapa sawit. Pabrik minyak kelapa sawit yang terpilih menjadi lokasi survei yaitu: (1) PT Naffasindo di Desa Bukit Harapan (2) PT Lembah Bakti di Desa Pandan Sari dan (3) PT Runding Putra Persada, di Desa Lae Pinang. Adapun responden terkait pabrik pengolahan minyak kelapa sawit adalah kepala Kepala Tata Usaha di masingmasing lokasi survei terpilih. 


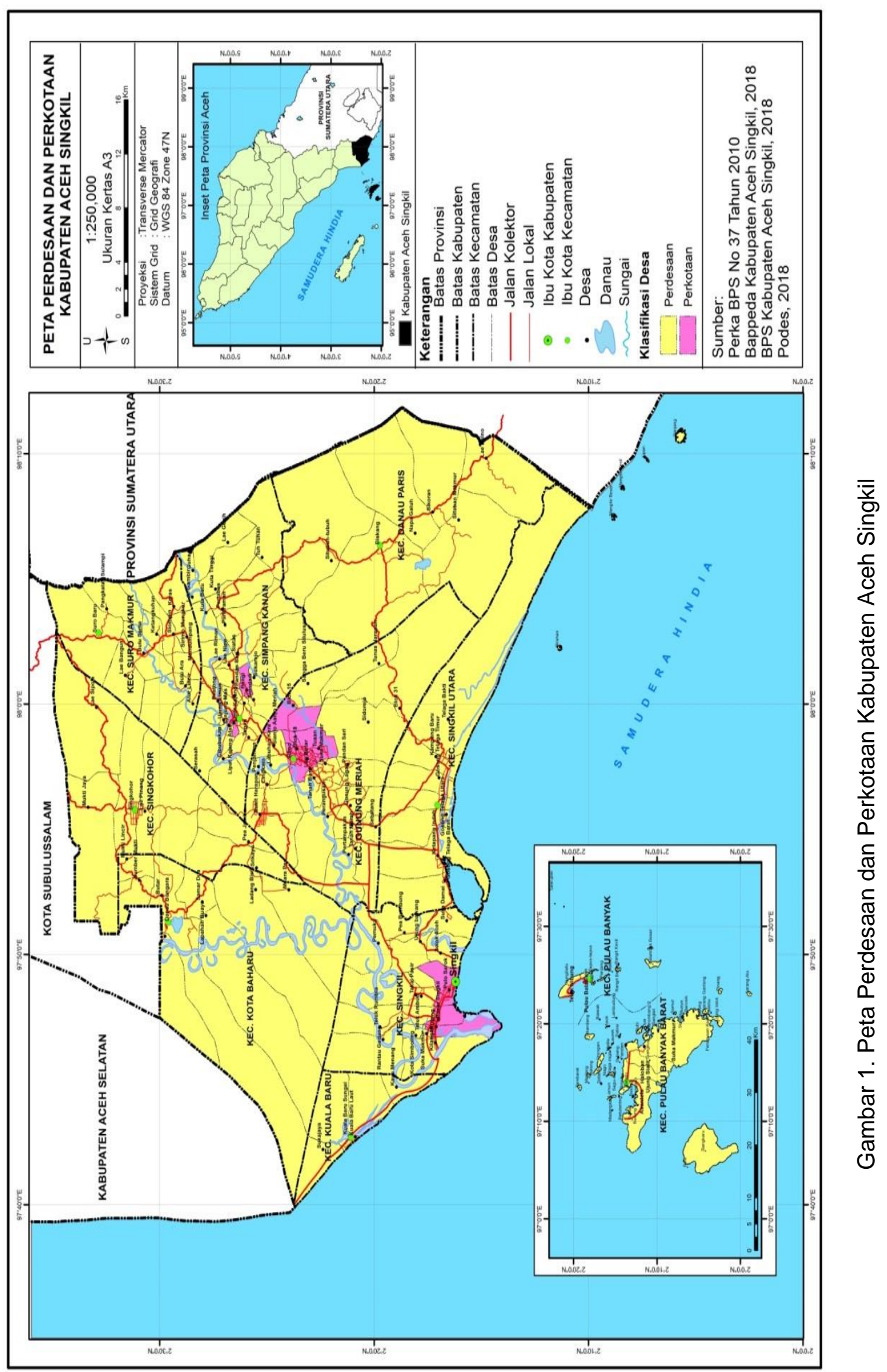




\section{Hasil dan Pembahasan}

Keterkaitan ekonomi merupakan keterkaitan yang paling esensial dalam hubungan yang terjadi antara perdesaan dan perkotaan. Kondisi aktual di lapangan menunjukkan beberapa hambatan keterkaitan ekonomi antara perdesaan dan perkotaan di Kabupaten Aceh Singkil. Rangkaian analisis beberapa indikator keterkaitan ekonomi antara perdesaan dan perkotaan yakni (a) aliran modal, (b) aliran belanja, (c) aliran bahan baku, (d) aliran barang setengah jadi, dan (e) aliran pendapatan, diuraikan sebagai berikut.

3.1 Aliran Modal

Keberlangsungan

usaha

perkebunan kelapa sawit sebagai entitas produksi ditentukan oleh kuantitas modal petani. Modal dalam bertani sawit merupakan akumulasi dari modal awal pembukaan lahan dan biaya pembelian sarana produksi. Rincian aliran modal yang diperoleh kelompok petani sawit dapat dilihat pada Tabel 2.

Tabel 2. Aliran Modal yang diperoleh Kelompok Tani

\begin{tabular}{|c|c|c|c|c|c|c|c|c|}
\hline \multirow[b]{2}{*}{ No } & \multirow[b]{2}{*}{ Lokasi } & \multirow[b]{2}{*}{ Klasifikasi } & \multicolumn{6}{|c|}{ Lokasi Fasilitas Pelayanan } \\
\hline & & & Koperasi & Lokasi & Klasifikasi & Perbankan & Lokasi & Klasifikasi \\
\hline 1 & $\begin{array}{l}\text { Desa } \\
\text { Penjahitan }\end{array}$ & Perdesaan & $\begin{array}{l}\text { Non } \\
\text { Aktif }\end{array}$ & - & - & Tidak ada & - & - \\
\hline 2 & $\begin{array}{l}\text { Desa } \\
\text { Sidorejo }\end{array}$ & Perdesaan & $\begin{array}{l}\text { Non } \\
\text { Aktif }\end{array}$ & - & - & Tidak ada & - & - \\
\hline 3 & $\begin{array}{l}\text { Desa } \\
\text { Tanah Bara }\end{array}$ & Perdesaan & Aktif & $\begin{array}{c}\text { Desa } \\
\text { Bukit } \\
\text { Hara- } \\
\text { pan }\end{array}$ & Perdesaan & Ada & $\begin{array}{l}\text { Desa } \\
\text { Rimo }\end{array}$ & Perkotaan \\
\hline 4 & $\begin{array}{l}\text { Desa } \\
\text { Sidodadi }\end{array}$ & Perdesaan & $\begin{array}{l}\text { Non } \\
\text { Aktif }\end{array}$ & - & - & Tidak ada & - & - \\
\hline 5 & $\begin{array}{l}\text { Desa } \\
\text { Sukerejo }\end{array}$ & Perdesaan & $\begin{array}{l}\text { Non } \\
\text { Aktif }\end{array}$ & - & - & Tidak ada & - & - \\
\hline 6 & $\begin{array}{l}\text { Desa Ujung } \\
\text { Bawang }\end{array}$ & Perdesaan & $\begin{array}{l}\text { Non } \\
\text { Aktif }\end{array}$ & - & - & Tidak ada & - & - \\
\hline
\end{tabular}

Sumber: Survei Lapangan, 2018

Berdasarkan hasil wawancara dengan beberapa ketua kelompok tani diketahui bahwa sebagian besar kelompok tani yang berasal dari perdesaan menggunakan modal sendiri dalam usaha perkebunannya, yakni sebanyak 5 kelompok tani atau 83\%. Adapun petani yang menggunakan jasa koperasi dan bank hanya 1 kelompok tani atau $17 \%$. Fasilitas koperasi yang dimanfaatkan petani terdapat di Desa Bukit Harapan, dan bank terdapat di Desa Rimo. Kondisi ini menjelaskan bahwa Desa Bukit Harapan yang berada di perdesaan dan Desa Rimo yang berada di perkotaan berperan sebagai pusat pelayanan permodalan, namun keberadaan fasilitas pelayanan permodalan sebagian besar belum diakses kelompok tani yang berasal dari perdesaan.
Aliran modal yang minim menunjukkan masih rendahnya kemampuan petani sawit untuk mengembangkan kegiatan usahanya. Sebagian besar kelompok petani juga tidak mendapat bantuan modal dari perusahaan swasta. Hal ini yang menjadi salah satu kendala dalam pengembangan usaha perkebunan di perdesaan. Hal ini ditegaskan Rijanta (2001) yang menyatakan bahwa peran bantuan keuangan di daerah perdesaan menjadi sangat penting dalam penyediaan kredit untuk petani Kredit tersebut dapat membantu meningkatkan produksi pertanian dan meningkatkan pertumbuhan usaha mikro.

\subsection{Aliran Belanja}

Aliran belanja usaha perkebunan terdiri dari sarana produksi yang 
dipergunakan untuk menghasilkan produk perkebunan, antara lain yakni bibit, pupuk, pestisida, dan alat pemanen. Interaksi wilayah dapat dilihat dari mobilitas petani untuk mendapatkan saprodi yang dibutuhkan, hal ini dapat dilihat dari asal petani dan lokasi fasilitas pelayanan jual beli saprodi. Rincian aliran belanja sarana produksi yang diperoleh kelompok petani sawit dapat dilihat pada Tabel 3.

Tabel 3. Aliran Belanja yang diperoleh Kelompok Tani

\begin{tabular}{cllcl}
\hline No & Lokasi Kelompok Tani & Klasifikasi & $\begin{array}{c}\text { Lokasi Toko Sarana } \\
\text { Produksi }\end{array}$ & Klasifikasi \\
\hline 1 & Desa Penjahitan & Perdesaan & Desa Rimo & Perkotaan \\
2 & Desa Sidorejo & Perdesaan & Desa Rimo & Perkotaan \\
3 & Desa Tanah Bara & Perdesaan & Desa Tanah Bara & Perdesaan \\
4 & Desa Sidodadi & Perdesaan & Desa Lipat Kajang & Perdesaan \\
5 & Desa Sukerejo & Perdesaan & Desa Lipat Kajang & Perdesaan \\
6 & Desa Ujung Bawang & Perdesaan & Desa Ujung bawang & Perdesaan \\
\hline
\end{tabular}

Sumber: Survei Lapangan, 2018

Berdasarkan hasil wawancara dengan beberapa ketua kelompok tani diketahui bahwa kebutuhan sarana produksi seluruh kelompok tani yang berasal dari perdesaan dapat dipenuhi oleh toko sarana produksi yang ada, dengan rincian sebagai berikut: 2 kelompok tani atau 34\% mendapatkan sarana produksi dari Desa Rimo yang berada diperkotaan, sedangkan 4 kelompok tani atau 66\% mendapatkan saprodi dari Desa Lipat Kajang, Desa Ujung Bawang, dan Desa Tanah Bara yang berada di perdesaan. Hal ini menandakan bahwa intensitas aliran belanja cenderung terjadi di perdesaan. Hal ini terjadi karena sebagian besar kebutuhan sarana produksi dapat dipenuhi di desa masing-masing atau pun di desa lainnya yang lokasinya berdekatan. Selaras dengan temuan tersebut, Herliany, dkk (2009) menyatakan bahwa preferensi penduduk perdesaan terhadap daya tarik fasilitas pelayanan menunjukkan bahwa lokasi fasilitas pelayanan yang dianggap ideal, salah satunya karena dekat dengan tempat tinggal

\subsection{Aliran Bahan Baku}

Bahan baku industri berupa tandan buah sawit merupakan produk perkebunan yang dominan di tiap desa. Aliran bahan baku berkaitan dengan alur distribusi produk hasil perkebunan yang akan di olah menjadi minyak kelapa sawit atau CPO (Crude Palm Oil). Rincian hasil aliran bahan baku dari kelompok tani dapat dilihat pada Tabel 4.

Tabel 4. Aliran Bahan Baku dari Kelompok Tani

\begin{tabular}{|c|c|c|c|c|c|}
\hline No & $\begin{array}{c}\text { Lokasi Kelompok } \\
\text { Tani }\end{array}$ & Klasifikasi & $\begin{array}{c}\text { Jenis } \\
\text { Distributor }\end{array}$ & Tujuan Pabrik & Klasifikasi \\
\hline 1 & Desa Penjahitan & Perdesaan & Agen & PT Naffasindo, di & \\
\hline 2 & Desa Sidorejo & Perdesaan & Agen & Desa Bukit & \\
\hline 3 & Desa Sidodadi & Perdesaan & Agen & Harapan, PT & \\
\hline 4 & Desa Sukerejo & Perdesaan & Agen & $\begin{array}{l}\text { Lembah Bakti, di } \\
\text { Desa Pandan Sari, }\end{array}$ & Perdesaan \\
\hline 5 & $\begin{array}{l}\text { Desa Ujung } \\
\text { Bawang }\end{array}$ & Perdesaan & Agen & $\begin{array}{l}\text { dan PT Runding } \\
\text { Putra Persada, di } \\
\text { Desa Lae Pinang }\end{array}$ & \\
\hline 6 & Desa Tanah Bara & Perdesaan & $\begin{array}{c}\text { Satuan } \\
\text { Pengumpul }\end{array}$ & $\begin{array}{l}\text { PT Naffasindo, di } \\
\text { Desa Bukit } \\
\text { Harapan }\end{array}$ & Perdesaan \\
\hline
\end{tabular}

Sumber: Survei Lapangan, 2018

72 | Media Komunikasi Geografi, Vol 20, No. 1, Juni 2019: 66-77 
Berdasarkan wawancara dengan beberapa ketua kelompok tani diketahui bahwa seluruh hasil produksi perkebunan dari kelompok tani yang berasal dari perdesaan dipasarkan menuju tiga pabrik pengolahan minyak kelapa sawit yang seluruhnya berada di perdesaan juga. Hal ini menandakan bahwa aliran bahan baku terjalin di perdesaan. Oleh karena itu dapat dikatakan bahwa aliran bahan baku tidak memiliki hubungan atau interaksi dengan perkotaan.

Pendistribusian hasil produksi perkebunan dilakukan dalam dua skema, yaitu (1) petani skala besar yang tergabung dengan koperasi yang berjumlah 1 kelompok tani atau 17\%, dengan rincian alur, petani skala besar ke satuan pengumpul dan ke pabrik, dan (2) petani skala kecil yang tidak tergabung dengan koperasi atau swadaya sebanyak 5 kelompok tani atau 83\%, dengan rincian alur, petani skala kecil ke agen desa ke satuan pengumpul dan ke pabrik. Alur pendistribusian hasil perkebunan secara detail dapat dilihat Gambar 2.

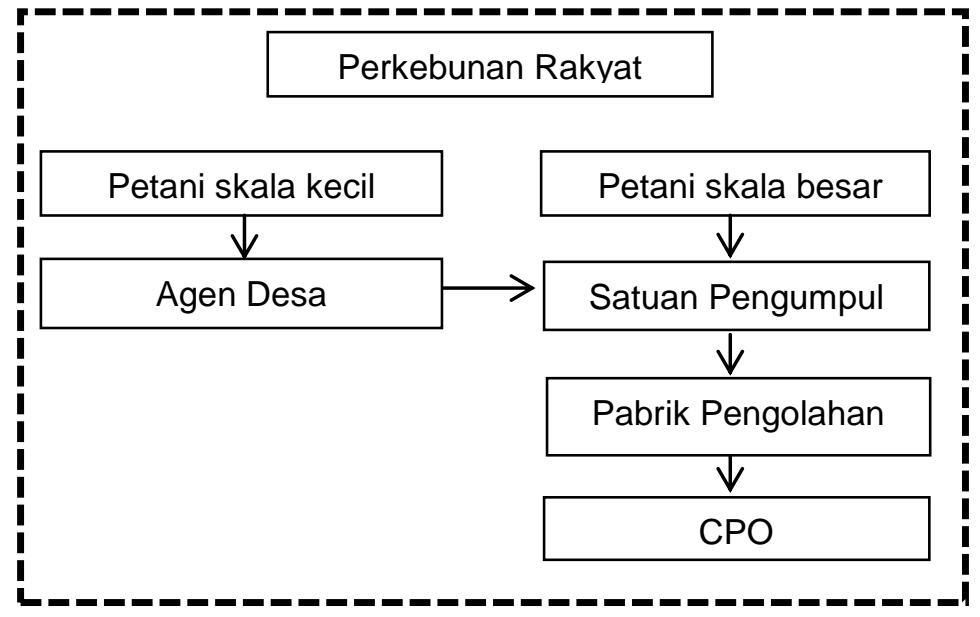

Gambar 2. Aliran Bahan Baku Tandan Buah Sawit

Panjangnya alur distribusi ini berkaitan dengan lahan perkebunan kelompok petani yang kecil-kecl dan tersebar serta jarak antara wilayah produksi menuju ke pabrik minyak kelapa sawit yang relatif jauh. Rantai penjualan tandan buah sawit yang panjang turut menyebabkan rendahnya keuntungan atas aktivitas ekonomi yang berlangsung. Menurut Rijanta (2001) jarak dari wilayah produksi menuju pusat pasar sangat menentukan pola aliran distribusi yang dipilih oleh petani swadaya. Semakin panjang alur distribusi, maka harga yang di peroleh petani lebih rendah sebagai akibat dari biaya transportasi yang dikeluarkan. Selain itu, nilai jual tandan buah sawit ditentukan oleh mekanisme pasar, dan petani perkebunan rakyat yang mengelola lahan mereka sendiri juga tidak berdaya karena seluruh pabrik pengolahan tandan buah kelapa sawit dikelola oleh perusahaan swasta.

3.4 Aliran Barang Setengah Jadi

Bahan baku yang diperoleh dari perkebunan rakyat selanjutnya diolah menjadi barang setengah jadi berupa CPO. Kegiatan industri pengolahan yang ada hanya sebatas area produksi CPO. Hasil produksi CPO didistribusikan kembali untuk diolah menjadi barang jadi. Rincian aliran barang setengah jadi dari perusahaan perkebunan dapat dilihat pada Tabel 5. 
Tabel 5. Aliran Barang Setengah Jadi (CPO) dari Perusahaan Perkebunan

\begin{tabular}{|c|c|c|c|c|c|}
\hline No & $\begin{array}{c}\text { Nama } \\
\text { Perusahaan }\end{array}$ & Lokasi & Klasifikasi & $\begin{array}{c}\text { Tujuan } \\
\text { Pemasaran }\end{array}$ & Tujuan ekspor \\
\hline 1 & PT Naffasindo & $\begin{array}{l}\text { Desa Bukit } \\
\text { Harapan }\end{array}$ & Perdesaan & $\begin{array}{l}\text { Pelabuhan } \\
\text { Belawan, } \\
\text { Medan }\end{array}$ & Malaysia \\
\hline 2 & $\begin{array}{l}\text { PT Lembah } \\
\text { Bakti }\end{array}$ & $\begin{array}{c}\text { Desa Pandan } \\
\text { Sari }\end{array}$ & Perdesaan & $\begin{array}{l}\text { Pelabuhan } \\
\text { Belawan, } \\
\text { Medan }\end{array}$ & Cina, Singapura \\
\hline 3 & $\begin{array}{l}\text { PT Runding } \\
\text { Putra Persada }\end{array}$ & $\begin{array}{l}\text { Desa Lae } \\
\text { Pinang }\end{array}$ & Perdesaan & $\begin{array}{l}\text { Pelabuhan } \\
\text { Belawan, } \\
\text { Medan }\end{array}$ & Singapura \\
\hline
\end{tabular}

Sumber: Survei Lapangan, 2018

Berdasarkan wawancara dengan beberapa KTU (Kepala Tata Usaha) pabrik diketahui bahwa seluruh hasil produksi CPO dikirim kembali keluar negeri melalui pelabuhan belawan yang terdapat di Kota Medan. Berdasarkan kondisi ini dapat dikatakan bahwa Kabupaten Aceh Singkil hanya sebagai area produksi sehingga Kota Medan sebagai pengekspor memperoleh nilai tambah (add value) lebih besar. Menurut Muta'ali (2014) daerah tertinggal cenderung hanya memproduksi produk primer, capital keluar dari daerah tertinggal ke daerah maju (backwash effect). Selain itu, produk daerah tertinggal masuk ke pasar luar negeri tanpa memberi nilai tambah (add value) bagi daerah tertinggal, di sisi lain capital dari luar negeri cenderung masuk ke daerah yang maju.

Hasil sumber daya alam yang besar pada wilayah ini pada akhirnya terserap oleh wilayah diluarnya, dan masyarakat hanya menkmati sedikit keuntungan. Tidak adanya nilai tambah (add value) dari hasil produksi turut menyebabkan minimnya kesempatan masyarakat lokal untuk meningkatkan taraf hidup. Menurut Kakazu (1994) salah satu faktor utama yang dapat meningkatkan produksi pertanian, memperluas lapangan kerja dan meningkatkan pendapatan bagi sebagian besar penduduk perdesaan adalah keterkaitan ekonomi yang erat dengan arus perdagangan daerah luar. Selaras dengan itu, Evans (1994) menyatakan bahwa peningkatan dan perubahan struktur ekonomi perdesaan dapat terjadi bila terdapat kemampuan masyarakat untuk menjual produk dan jasa ke pasaran luar kawasan, terjadi transaksi ekonomi antara produsen dan pembeli, antar sektor usaha, antar daerah bahkan negara lain.

\subsection{Aliran pendapatan}

Petani mendapatkan sejumlah keuntungan atau pendapatan dari hasil penjualan tandan buah sawit. Pendapatan petani pada dasarnya dipengaruhi oleh jumlah tandan buah sawit dan harga jual tandan buah sawit yang ditetapkan pada saat transaksi. Penetapan harga tandan buah sawit dilakukan oleh Pemerintah Provinsi, pemerintah Kabupaten/Kota, Dinas Perkebunan, dan Perusahaan. Harga pembelian tandan buah sawit ditetapkan minimal satu bulan sekali sesuai dengan realisasi penjualan ekspor dan lokal masing-masing perusahaan (Peraturan Menteri Pertanian Nomor 395 Tahun 2005). Meskipun harga tandan buah sawit tidak stabil, sektor perkebunan tetap menjadi sumber mata pencaharian penduduk di Kabupaten Aceh Singkil. Rincian pendapatan masing-masing anggota kelompok tani dapat dilihat pada Tabel 6. 
Tabel 6. Aliran Pendapatan yang diterima Kelompok Tani

\begin{tabular}{|c|c|c|c|}
\hline No & Lokasi Kelompok Tani & Klasifikasi & $\begin{array}{c}\text { Rata-Rata } \\
\text { Pendapatan tiap } \\
\text { anggota per-bulan } \\
(\mathrm{Rp})\end{array}$ \\
\hline 1 & Desa Penjahitan & Perdesaan & 800.000 \\
\hline 2 & Desa Sidorejo & Perdesaan & 1.600 .000 \\
\hline 3 & Desa Tanah Bara & Perdesaan & 1.400 .000 \\
\hline 4 & Desa Sidodadi & Perdesaan & 1.300 .000 \\
\hline 5 & Desa Sukerejo & Perdesaan & 1.400 .000 \\
\hline 6 & Desa Ujung Bawang & Perdesaan & 1.100 .000 \\
\hline \multicolumn{3}{|c|}{$\begin{array}{l}\text { Rata-rata pendapatan tiap anggota } \\
\text { seluruh kelompok tani per bulan }(\mathrm{Rp})\end{array}$} & 1.250 .000 \\
\hline
\end{tabular}

Sumber: Survei Lapangan, 2018

Berdasarkan hasil wawancara dengan beberapa kelompok tani dapat diketahui aliran pendapatan yang diterima kelompok tani yang berada pada di perdesaan berasal dari pabrik yang berada perdesaan juga. Adapun rata-rata bahwa pendapatan yang diterima petani perbulannya sebesar $\mathrm{Rp}$ 1.250.000. Jumlah pendapatan petani ini lebih rendah jika dibandingkan dengan UMP (Upah Minimum Provinsi) yang berlaku di Provinsi Aceh tahun 2018 dengan besaran nominal Rp 2.700.000 (Peraturan Gubernur Aceh Nomor 67 Tahun 2017). Hal ini menunjukkan bahwa hasil dari perkebunan kelapa sawit tidak mengarahkan pada kesejahteraan petani. Rendahnya daya tawar petani untuk menjual hasil buah sawit dikarenakan adanya agen dan satuan pengumpul, minimnya aliran modal serta beban biaya produksi yang tinggi. Selaras dengan temuan tersebut, Rondinelli (1983) menyatakan bahwa minimnya akses wilayah perdesaan terhadap pusat-pusat pelayanan yang terintegrasi maka penduduk pedesaan akan mengalami kesulitan di dalam pemasaran hasil pertanian, sulit mendapatkan input-output produksi, dan mendapatkan pelayananpelayanan yang dibutuhkan untuk meningkatkan kualitas hidup dipedesaan.

Selain itu, rendahnya pendapatan petani dikarenakan nilai jual tandan buah sawit ditentukan oleh mekanisme pasar.
Petani akan kehilangan kontrol terhadap mata pencaharian mereka sendiri. Petani perkebunan rakyat yang mengelola lahan mereka sendiri juga tidak berdaya karena seluruh pabrik pengolahan tandan buah kelapa sawit dikelola oleh perusahaan swasta.

\section{Kesimpulan}

Berdasarkan beberapa kondisi keterkaitan perdesaan dan perkotaan yang telah diuraikan sebelumnya, didapati bahwa kegiatan perkebunan di perdesaan dan interaksinya terhadap fasilitas pelayanan yang terdapat diperkotaan belum terjalin secara lugas. Sebagian besar kelompok tani belum mengakses fasilitas pelayanan permodalan yang terdapat di perkotaan, sedangkan kebutuhan sarana produksi sebagian besar dapat dipenuhi oleh toko penjual sarana produksi yang berada di perdesaan. Aliran bahan baku terjalin di wilayah perdesaan. Pendistribusian hasil produksi perkebunan sebagian besar dilakukan oleh agen desa ke satuan pengumpul lalu ke pabrik. Rantai penjualan tandan buah sawit yang panjang turut menyebabkan minimnya pendapatan yang diterima petani. Adapun pendapatan yang diterima petani jauh dibawah standar UMR (Upah Minimum Regional) yang berlaku. Selain itu, kegiatan industri yang dikembangkan melalui pabrik pengolahan minyak kelapa swasta hanya sebatas area produksi CPO 
(Crude Palm Oil). Seluruh hasil produksi CPO diekspor ke Malaysia, Cina, dan Singapura melalui pelabuhan Belawan yang berlokasi di Kota Medan, sehingga perolehan nilai tambah (add value) masuk ke wilayah luar. Berdasarkan kondisi aktual tersebut, dapat disimpulkan bahwa perdesaan dan perkotaan berkembang sendiri-sendiri seolah terpisah atau dapat dikatakan bahwa tidak terjadi hubungan secara fungsional dalam suatu struktur ruang. Terbatasnya keterkaitan antara perdesaan dengan perkotaaan akan berpotensi menimbulkan kesenjangan pembangunan dan tingginya angka kemiskinan, khususnya di perdesaan. Hal tersebut turut berimplikasi terhadap terbentuknya daerah tertinggal di Kabupaten Aceh Singkil.

Saran yang dapat diberikan sebagai kontribusi dari penelitian ini adalah sebaiknya dilakukan upaya pengembangan kapasitas fasilitas pelayanan pada perdesaan dan perkotaan, khususnya fasilitas pelayanan dasar dan fasilitas yang mendukung pengembangan sektor perkebunan dan industri seperti kios saprodi, koperasi, bank, dan pabrik. Adapun pengembangan wilayah perdesaan sebagai wilayah sentra produksi perkebunan dapat diupayakan melalui jalinan kemitraan antara kelompok tani, koperasi, dan perusahaan perkebunan swasta. Keuntungan yang diperoleh dari kemitraan ini yaitu, memperpendek rantai penjualan produk perkebunan, kemudahan mendapatkan sarana produksi, legalitas akses permodalan ke bank, dan meningkatkan keuntungan dari usaha perkebunan.

\section{Ucapan Terimakasih}

Ucapan terima kasih penulis sampaikan kepada Prof. Dr .R Rijanta, M.Sc, dan Dr. Dyah Rahmawati Hizbaron S.Si, M.T, M.Sc yang telah membimbing dan memberi masukan dalam penyelesaian penelitian ini, serta segala pihak yang telah membantu penyelesaian penelitian.

\section{Daftar Pustaka}

Badan Perencanaan Pembangunan Nasional. 2016, Seri Pembangunan Wilayah Provinsi Aceh 2015. Jakarta: Bappenas.

Badan Pusat Statistik, Kabupaten Aceh Singkil dalam Angka 2017, Singkil: BPS.

Badan Pusat Statistik, Provinsi Aceh dalam Angka 2017, Aceh: BPS.

Dinas Kehutanan dan Perkebunan. 2018. Luas Areal dan Produksi Komoditas Perkebunan Rakyat Kabupaten Aceh Singkil Angka Tetap Tahun 2017, Singkil: Dishutbun.

Evans, H, Ermy. 1994. Rural Urban Linkages : Operational Implications for Self Sustained Development. Pratical Research For Planning. Inc.

Muta'ali, Lutfi. 2014, Pengembangan Wilayah Tertinggal. Yogyakarta :Badan Penerbit Fakultas Geografi (BPFG) UGM.

Peraturan Presiden Nomor 131 tahun 2015 Tentang Penetapan Daerah tertinggal.

Peraturan Gubernur Aceh Nomor 67 Tahun 2017 Tentang Upah Minimum Regional di Provinsi Aceh.

Peraturan Kepala Badan Pusat Statistik No 37 Tahun 2010 Tentang Klasifikasi Perdesaan dan Perkotaan.

Peraturan Menteri Pertanian No 324 Tahun 2005 tentang Penetapan Harga Tandan Buah Sawit.

Rondinelli, 1983. Applied Methods of Regional Planning: The Urban Functions In Rural Development Approach. Clark University,Worcester. 
Rondinelli, 1985. Applied Methods of Regional Analysis. Colorado: Westview Press.

Undang-Undang Nomor 14 Tahun 1999 Tentang Pembentukan Daerah Tingkat II Kabupaten Aceh Singkil.

Rijanta, R. 2001. Rural-Urban Linkage in A Resource Frontier Region: The Case of Sorong, Irian Jaya, Indonesia. The Indonesian Journal of Geography Vol 33, No 2 Desember 2001, pp. 59-81.

Kakazu, Hiroshi. 1994. Sustainable Development of Small Island Economic. San Fransisco: Westview Press.

Herliany, lis. Rijanta, R. Rahmawati R. 2009. Perbandingan Preferensi pelayanan Ekonomi Penduduk Rural dan Urban di Kabupaten Sleman. Majalah Geografi Indonesia Vol. 23, No.1, Maret 2009. 58-76. Fakultas Geografi Universitas Gadjah Mada. 